\title{
Some factors of the time of breaking and training affecting racing performance in young trotters
}

\author{
M.T. SAASTAMOINEN \\ Agricultural Research Centre, Equine Research Station, \\ SF-32100 Ypäjä, Finland
}

\begin{abstract}
Saastamoinen, M.T. (Agricultural Research Center, Equine Research Station, SF-32100 Ypäjä, Finland). Some factors of the time of breaking and training affecting racing performance in young trotters.

An inquiry study was carried out to query the main reasons for non-starting and poor racing results, as well as to estimate the effect of some factors of the time of breaking and training on racing performance. The numbers of acceptable responses were 796 for Standardbred trotters and 857 for Finnhorses. About $72 \%$ of the Standardbred trotters raced before the end of the five-year season, and about $42 \%$ of the Finnhorse trotters raced before the end of their six-year season. The main reasons for non-starting and poor racing results were injuries and ailments, bad character, lack of talent and poor training. In general, young age at the beginning of breaking and training was favorably associated with racing performance. For instance, three-year-old Standardbred trotters broken at the age of 1 or $1 \frac{1}{2}$ years were 2.1 seconds faster $(\mathrm{p}<0.01)$ and had a larger number of starts $(\mathrm{p}<0.05)$ than their racemates broken at $\mathbf{2}$ or 3 years of age. The influence of class of persons responsible for breaking and training was minor. However, trotters broken and trained by professional trainers seemed to have better racing results than trotters broken and trained by breeders and owners.
\end{abstract}

Index words: horse, trotting, racehorse, environmental factors

\section{Introduction}

Environmental factors affecting the racing performance of trotters can be classified by long, middle and short term effects (KATONA 1985). Long term effects include the influences of breeder, birth year, season of birth as well as age and sex of the horse. The influence of training and racing year are middle term ef- fects. Short term effects include factors affecting performance in a single race.

Racing performance may also be affected by several factors arising during the breaking and training periods. These include e.g. injuries, ailments and bad character.

The possible effects of training on racing performance may be due to differences in the methods employed by different persons car- 
rying out breaking and training. A horse's age at the onset of breaking and training may also influence racing performance. Starting training at young age is supposed to be advantageous both to the development of young horses and their racing performance (RONEUS 1987, Lindholm 1988, 1990).

The purpose of this study was to query reasons for nonstarting and poor racing results of trotters. Another aim was to estimate the influence of the age at onset of breaking and training, as well as the influence of persons responsible for breaking and training, on racing performance in young trotters.

\section{Materials and methods}

A questionnaire was sent out to both owners of Standardbred trotters born in 1981 and 1982, and to those owning Finnhorses born in 1980 and 1981. The number of inquiries sent out was 1810 and 1995, to Standardbred and Finnhorse owners, respectively.

The response percentages were 46.5 for Standardbred trotters and 46.8 for Finnhorses, with no reminders sent. Thus, the total number of replies was 841 for Standardbred trotters, and 934 for Finnhorses.

The numbers of acceptable responses were 796 (361 born in 1981, 435 born in 1982) for Standardbred trotters, and 857 (389 born in 1980, 468 born in 1981) for Finnhorses. These horses were approximately $35 \%$ of each crop born. The proportion of males (stallions or geldings) was $47 \%$ in Standardbred trotters and $58 \%$ in Finnhorses.

In the data the number of Standardbred trotters raced before the end of the five-year season was 589 (72\% of all horses), and the number of Finnhorse trotters raced before the end of the six-year season was 391 (42\%). For Finnish Standardbred trotters born in 1981 and 1982 the proportion of horses raced before the end of the five-year season was about $65 \%$ (ANON. 1983, 1984, 1985, 1986, 1987). In the case of Finnhorses born in 1980 and 1981 , the proportion of horses raced before the end of the six-year season was about $45 \%$.

Only a few Standardbred trotters started racing at two years of age, and the starting frequency of 2-year-old Standardbred trotters was distinctly smaller than that of 3-year-old Finnhorse trotters (Table 1). Percentages of horses raced at different age classes in Standardbred trotters were in agreement with the statistics on Finnish trotter population (ANON. 1983, 1984, 1985, 1986, 1987). In Finnhorses the percentages were smaller than reported for the whole population, as shown in Table 1.

The data consisted of age at onset of breaking and training, persons charged with breaking and training, as well as the annually summarised race records for 3 through 5-year-old Finnish Standardbred trotters and 4 through 6-year-old Finnhorse trotters. The data also included information on sire, sex, birth-month class (January-March, April, May, June, July, August-November) and birth year of the horse.

Age at the onset of breaking and training was determined within the accuracy of one half or one year (Table 2). The age of a horse is calculated from the first of January of the birth year (ANON. 1987b).

For the statistical analyses, the horses were classified according to their age at the onset of breaking or age at the onset of training. The class “early broken"' included Standardbred trotters that started breaking at 1 or $1 \frac{1}{2}$ years of age and Finnhorses that started breaking at $1 \frac{1 / 2}{2}$ or 2 years of age. The class "late broken" included Standardbred trotters that started breaking at 2 or 3 years of age and Finnhorses that started breaking at 3 or 4 years of age.

Similarly, the class "early trained" included Standardbred trotters that started training at the age of $1 \frac{1}{2}$ or 2 years and Finnhorses starting training at the age of 2 or 3 years. Standardbred trotters whose training began at 3 or 4 years of age, and Finnhorses trained beginning at 4 or 5 years of age, belonged to class "late trained".

Persons in charge of breaking and training 
were classified as breeders, owners and professional trainers (Table 3). The largest group responsible for breaking was breeders in both breeds.
Traits representing a horse's annual racing performance were best racing time on voltstart, number of starts, fourth root of earnings, logit transformation of first placings,

Table 1. Number and percentage of horses raced at different age classes.

\begin{tabular}{|c|c|c|c|c|c|c|c|}
\hline \multirow[t]{2}{*}{ Age class } & \multicolumn{2}{|c|}{ Data } & \multirow{2}{*}{$\begin{array}{c}\begin{array}{c}\text { Anon. } \\
(1983-87)\end{array} \\
\%\end{array}$} & \multirow[t]{2}{*}{ Age class } & \multicolumn{2}{|c|}{ Data } & \multirow{2}{*}{$\begin{array}{c}\begin{array}{c}\text { Anon. } \\
(1983-87)\end{array} \\
\%\end{array}$} \\
\hline & $\mathbf{n}$ & $\%$ & & & $\mathbf{n}$ & $\%$ & \\
\hline \multicolumn{4}{|c|}{ Standardbred trotters } & \multicolumn{3}{|c|}{ Finnhorse trotters } & \\
\hline 2 & 14 & 1.8 & 1.2 & 3 & 92 & 10.8 & 7.9 \\
\hline 3 & 289 & 36.3 & 35.6 & 4 & 221 & 25.8 & 34.9 \\
\hline 4 & 478 & 60.1 & 60.1 & 5 & 287 & 33.5 & 44.0 \\
\hline 5 & 449 & 56.4 & 58.5 & 6 & 357 & 41.7 & 44.9 \\
\hline
\end{tabular}

Table 2. Number and percentage of 3 to 5-yr-old Standardbred trotters and 4 to 6-yr-old Finnhorse trotters in different age classes at onset of breaking and training.

\begin{tabular}{|c|c|c|c|c|c|c|c|c|c|c|c|c|c|}
\hline \multirow[t]{3}{*}{ Age } & \multicolumn{6}{|c|}{ Standardbred trotters } & \multirow[t]{3}{*}{ Age } & \multicolumn{6}{|c|}{ Finnhorse trotters } \\
\hline & \multicolumn{2}{|c|}{3} & \multicolumn{2}{|c|}{4} & \multicolumn{2}{|c|}{5} & & \multicolumn{2}{|c|}{4} & \multicolumn{2}{|c|}{5} & \multicolumn{2}{|c|}{6} \\
\hline & $\mathrm{n}$ & $\%$ & $\mathbf{n}$ & $\%$ & $\mathbf{n}$ & $\%$ & & $\mathrm{n}$ & $\%$ & $\mathrm{n}$ & $\%$ & $\mathrm{n}$ & $\%$ \\
\hline \multicolumn{7}{|c|}{ Age at breaking } & \multicolumn{7}{|c|}{ Age at breaking } \\
\hline 1 & 36 & 13 & 48 & 10 & 47 & 11 & $11 / 2$ & 63 & 29 & 76 & 27 & 88 & 25 \\
\hline $11 / 2$ & 145 & 50 & 241 & 50 & 209 & 47 & 2 & 94 & 42 & 113 & 39 & 136 & 38 \\
\hline 2 & 94 & 32 & 147 & 31 & 141 & 31 & 3 & 57 & 26 & 75 & 26 & 91 & 25 \\
\hline 3 & 14 & 5 & 42 & 9 & 52 & 11 & 4 & 7 & 3 & 23 & 8 & 42 & 12 \\
\hline \multicolumn{7}{|c|}{ Age at training } & \multicolumn{7}{|c|}{ Age at training } \\
\hline $11 / 2$ & 22 & 8 & 24 & 5 & 22 & 5 & 2 & 8 & 4 & 11 & 4 & 11 & 3 \\
\hline 2 & 134 & 48 & 186 & 40 & 164 & 37 & 3 & 116 & 53 & 115 & 41 & 132 & 38 \\
\hline 3 & 122 & 43 & 226 & 48 & 212 & 48 & 4 & 87 & 40 & 131 & 47 & 152 & 44 \\
\hline 4 & 4 & 1 & 32 & 7 & 42 & 10 & 5 & 7 & 3 & 24 & 8 & 52 & 15 \\
\hline
\end{tabular}

Table 3. Number and percentage of 3 to 5-yr-old Standardbred trotters and 4 to 6-yr-old Finnhorse trotters in different classes of instructor and trainer.

$\mathbf{B}=$ breeder, $\mathbf{O}=$ owner, $\mathrm{PT}=$ professional trainer.

\begin{tabular}{|c|c|c|c|c|c|c|c|c|c|c|c|c|c|}
\hline \multirow[t]{3}{*}{ Age } & \multicolumn{6}{|c|}{ Standardbred trotters } & \multirow[t]{3}{*}{ Age } & \multicolumn{6}{|c|}{ Finnhorse trotters } \\
\hline & \multicolumn{2}{|c|}{3} & \multicolumn{2}{|c|}{4} & \multicolumn{2}{|c|}{5} & & \multicolumn{2}{|c|}{4} & \multicolumn{2}{|c|}{5} & \multicolumn{2}{|c|}{6} \\
\hline & $\mathrm{n}$ & $\%$ & $\mathrm{n}$ & $\%$ & $\mathrm{n}$ & $\%$ & & $\mathrm{n}$ & $\%$ & $\mathrm{n}$ & $\%$ & $\mathrm{n}$ & $\%$ \\
\hline \multicolumn{7}{|c|}{ At breaking } & \multicolumn{7}{|c|}{ At breaking } \\
\hline B & 109 & 39 & 184 & 39 & 169 & 38 & B & 118 & 54 & 153 & 54 & 186 & 53 \\
\hline $\mathrm{O}$ & 86 & 30 & 144 & 31 & 146 & 34 & $\mathrm{O}$ & 89 & 40 & 117 & 41 & 153 & 43 \\
\hline PT & 88 & 31 & 141 & 30 & 125 & 28 & PT & 13 & 6 & 15 & 5 & 15 & 4 \\
\hline \multicolumn{7}{|c|}{ At training } & \multicolumn{7}{|c|}{ At training } \\
\hline B & 71 & 26 & 130 & 28 & 112 & 26 & B & 80 & 37 & 111 & 40 & 133 & 39 \\
\hline O & 84 & 30 & 141 & 31 & 149 & 35 & O & 102 & 47 & 130 & 46 & 167 & 48 \\
\hline PT & 122 & 44 & 189 & 41 & 170 & 39 & PT & 35 & 16 & 39 & 14 & 45 & 13 \\
\hline
\end{tabular}


logit of first-to-third placings and logit of disqualified races.

The data were analysed by the Least Squares Analysis. The following linear models were assumed for each age class within breeds:

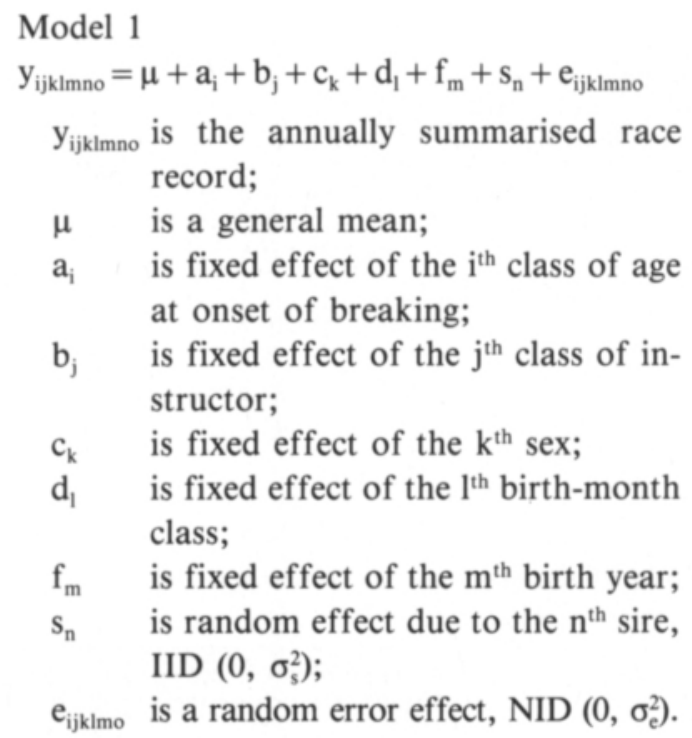

Model 2

$\mathrm{y}_{\mathrm{ijk} \text { lmno }}=\mu+\mathrm{a}_{\mathrm{i}}+\mathrm{b}_{\mathrm{j}}+\mathrm{c}_{\mathrm{k}}+\mathrm{d}_{1}+\mathrm{f}_{\mathrm{m}}+\mathrm{s}_{\mathrm{n}}+\mathrm{e}_{\mathrm{ijk} \mathrm{k} \text { mno }}$

In model 2 a-effect was the class of age at onset of training and b-effect was the class of trainer. All other elements were defined as in model 1.

\section{Results}

\section{Reasons for non-starting and poor performance}

The incidence of different reasons for nonstarting and poor racing results varied between the breeds (Fig. 1 and 2). However, the main reasons for non-starting in both breeds were injuries and ailments, as well as transferring to breeding (mares). Other important reasons were lack of talent, bad character and growth abnormalities which were separated from other diseases.

About $63 \%$ of the Standardbred trotters and $62 \%$ of the Finnhorse trotters succeeded worse in their races than their owners had expected. The most important reasons for poor racing performance in both breeds were diseases and injuries, poor training and bad character.

Diseases and injuries, as reasons for nonstarting and poor performance, were more common among trotters trained by professional trainers than among those trained by breeders and owners. They were also more frequent in males than in females.

\section{Factors affecting racing performance}

Class of age at onset of breaking. In general, young age at the beginning of both breaking and training was favorably associated with racing performance. Three-year-old Standardbred trotters that started breaking at the age of 1 or $1 \frac{1}{2}$ years were 2.1 seconds faster $(p<0.01)$ and also had a larger number of starts $(\mathrm{p}<0.05)$ ( 2 starts more) than their racemates broken at 2 or 3 years of age (Table 4 ). The "early broken" Standardbred trotters had larger earnings at five years of age than their "late broken" contemporaries $(p<0.001)$.

Five-year-old Finnhorse trotters that started breaking at the age of $1 \frac{1}{2}$ or 2 years had larger earnings and larger number of first placings than horses broken at 2 or 3 years of age $(p<0.01)$. The “early broken" Finnhorses had a larger number of first placings $(\mathrm{p}<0.001)$ and first-to-third placings $(\mathrm{p}<0.01)$ at the age of six years than their "late broken" racemates.

Class of age at onset of training. Three- and four-year-old Standardbred trotters that started training at $1 \frac{1}{2}$ or 2 years of age were faster $(\mathrm{p}<0.01$ and $\mathrm{p}<0.05)$ than their contemporaries who started at 3 or 4 years of age (Table 5). Young age at the beginning of training was also advantageous for the number of starts in 3-year-old Standardbred trotters $(\mathrm{p}<0.001)$.

In Finnhorses, four-, five- and six-year-old trotters whose training began at 2 or 3 years of age were faster $(p<0.01$ or 0.05$)$ than their racemates started training at 4 or 5 years of 


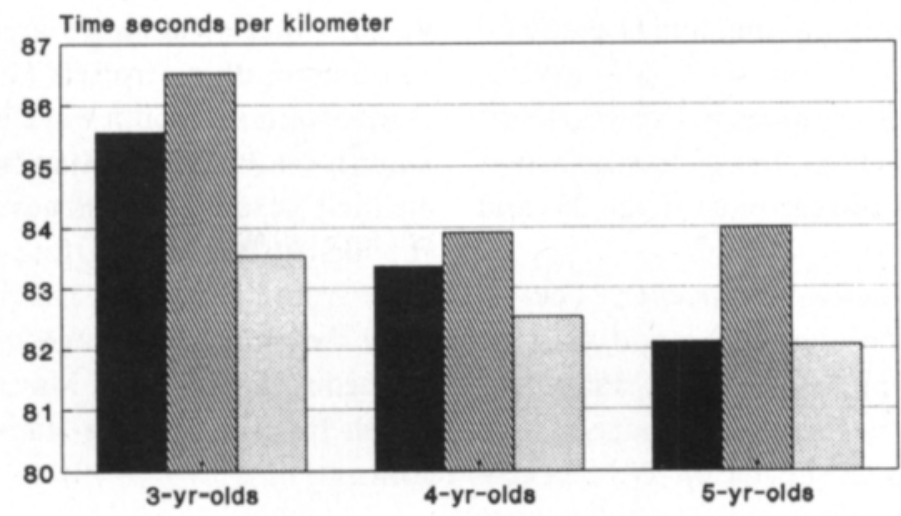

Breeder $\quad \square$ Owner $\square$ Professional trainer

Fig. 1a

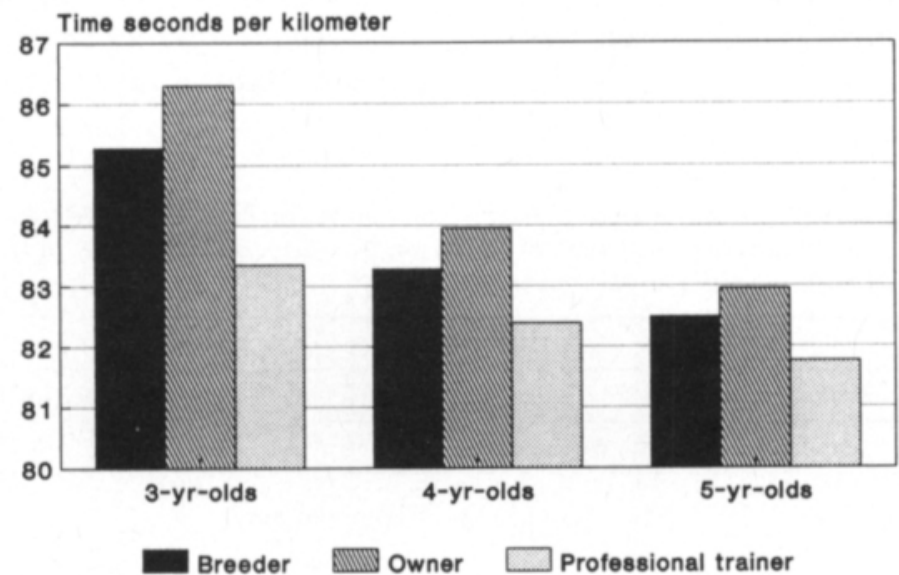

Fig. 1b

Fig. 1. Reasons for non-starting in Standardbred trotters (a) and Finnhorse trotters (b).

\section{Standardbred trotters}

$n=219$

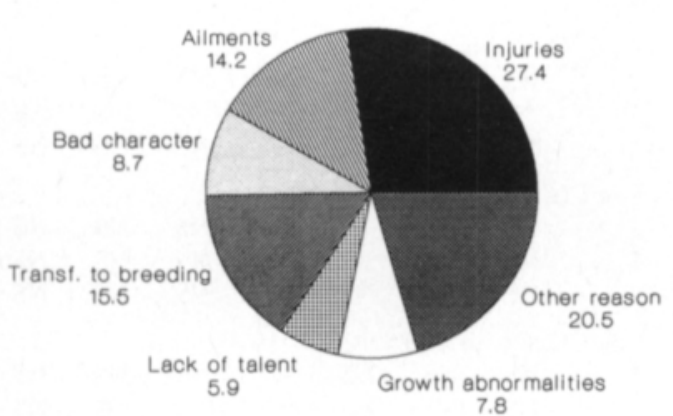

Fig. 2a
Finnhorse trotters

$n=434$

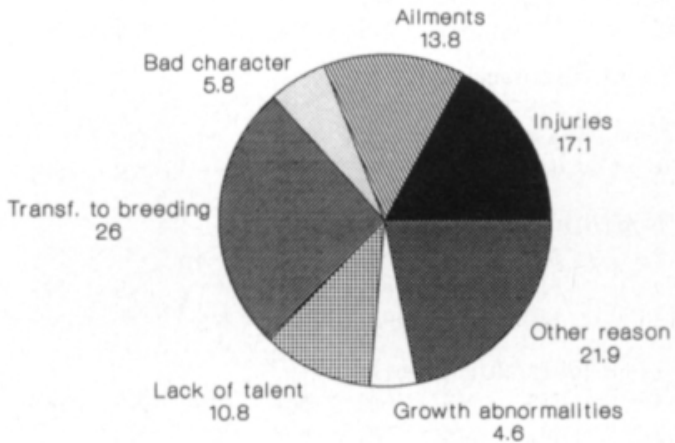

Fig. 2b

Fig. 2. Reasons for poor racing performance in Standardbred trotters (a) and Finnhorse trotters (b). 
age (Table 5). Early training was also advantageous for the number of starts in four-yearolds $(\mathrm{p}<0.01)$, for earnings in five-year-olds, and for the number of first-to-third placings in four- and five-year-olds $(\mathrm{p}<0.05$ and $\mathrm{p}<0.01)$.

Class of instructor and trainer. The influence of class of instructor and class of trainer on racing performance was statistically significant only in three- and four-year-old Standardbred trotters (Table 4). Trotters broken or trained by professional trainers were faster $(\mathrm{p}<0.05$ to $\mathrm{p}<0.01)$ than trotters broken or trained by breeders and owners (Fig. 3).

Sex, birh-month class and birth year. In general, in both breeds and in all age classes, males were superior to females. The differ- ences between sexes were largest in four-yearold Standardbred trotters (Table 4). The influence of birth month was statistically significant $(\mathrm{p}<0.05)$ only in Standardbred trotters. In their case, the most advantageous birth months for three- and four-year-old horses were from January to March For five-yearolds the most advantageous birth months seemed to be April and May. Differences between birth years were statistically non-significant.

\section{Discussion}

Reasons for non-starting and poor racing performance. Injuries and ailments included different diseases and accidents, and might

Table 4. Statistical significance of the effects of fixed factors on racing performance (F-test).

$1=$ class of age at onset of breaking, 2 = class of instructor, $3=$ class of age at onset of training, $4=$ class of trainer, $5=\operatorname{sex}, 6=$ birth month class, $7=$ birth year.

\begin{tabular}{|c|c|c|c|c|c|c|c|c|c|c|c|c|c|c|}
\hline \multicolumn{15}{|c|}{ F-test for } \\
\hline \multicolumn{8}{|c|}{ Standardbred trotter } & \multicolumn{7}{|c|}{ Finnhorse trotter } \\
\hline & 1 & 2 & 3 & 4 & 5 & 6 & 7 & 1 & 2 & 3 & 4 & 5 & 6 & 7 \\
\hline \multicolumn{8}{|c|}{ Trait and age } & \multicolumn{7}{|l|}{ Trait and age } \\
\hline \multicolumn{8}{|c|}{ Best time } & \multicolumn{7}{|l|}{ Best time } \\
\hline 3 & $* *$ & $* *$ & $* *$ & $* *$ & NS & NS & NS & NS & NS & $* *$ & NS & NS & NS & NS \\
\hline 4 & NS & $* *$ & $\bullet$ & $*$ & $*$ & NS & NS & NS & NS & $* *$ & NS & NS & NS & NS \\
\hline 5 & NS & NS & NS & NS & NS & $*$ & NS & NS & NS & $*$ & NS & $*$ & NS & NS \\
\hline \multicolumn{8}{|c|}{ Number of starts } & \multicolumn{7}{|c|}{ Number of starts } \\
\hline 3 & $*$ & NS & $* * *$ & NS & NS & NS & NS & NS & NS & $* *$ & NS & NS & NS & NS \\
\hline 4 & NS & NS & NS & NS & $* * *$ & NS & NS & NS & NS & NS & NS & NS & NS & NS \\
\hline 5 & NS & NS & NS & NS & NS & NS & NS & NS & NS & NS & NS & $*$ & NS & NS \\
\hline \multicolumn{8}{|c|}{ (Earnings) $)^{1 / 4}$} & \multicolumn{7}{|l|}{ (Earnings) ${ }^{\mathrm{k}}$} \\
\hline 3 & NS & $*$ & NS & NS & NS & $*$ & NS & NS & NS & NS & NS & NS & NS & NS \\
\hline 4 & NS & NS & NS & NS & NS & $* *$ & NS & $* *$ & NS & $* *$ & NS & NS & NS & NS \\
\hline 5 & $* * *$ & NS & NS & NS & NS & NS & NS & NS & NS & NS & NS & $*$ & NS & NS \\
\hline \multicolumn{8}{|c|}{ Logit (first placings) } & \multicolumn{7}{|c|}{ Logit (first placings) } \\
\hline 3 & NS & NS & NS & NS & NS & $*$ & NS & NS & NS & NS & NS & NS & NS & NS \\
\hline 4 & NS & NS & NS & NS & $*$ & NS & NS & $* *$ & NS & NS & NS & NS & NS & NS \\
\hline 5 & NS & NS & NS & NS & $* *$ & NS & NS & $* * *$ & NS & NS & NS & NS & NS & NS \\
\hline \multicolumn{8}{|c|}{ Logit (first-to-third-placings) } & \multicolumn{7}{|c|}{ Logit (first-to-third placings) } \\
\hline 3 & NS & NS & NS & NS & NS & $*$ & NS & NS & NS & $*$ & NS & NS & NS & NS \\
\hline 4 & NS & NS & NS & NS & $* *$ & NS & NS & NS & NS & $*$ & NS & NS & NS & NS \\
\hline 5 & NS & NS & NS & NS & NS & $*$ & NS & $* *$ & NS & NS & NS & NS & NS & NS \\
\hline \multicolumn{8}{|c|}{ Logit (disqualified races) } & \multicolumn{7}{|c|}{ Logit (disqualified races) } \\
\hline 3 & NS & NS & NS & NS & NS & NS & NS & NS & NS & NS & NS & NS & NS & NS \\
\hline 4 & NS & NS & NS & NS & NS & NS & NS & NS & NS & NS & NS & NS & NS & NS \\
\hline 5 & NS & NS & NS & NS & NS & NS & NS & NS & NS & NS & NS & NS & NS & NS \\
\hline
\end{tabular}

Levels of statitical significance: ${ }^{* * *} \mathrm{p}<0.001,{ }^{* *} \mathrm{p}<0.01,{ }^{*} \mathrm{p}<0.05$, NS non-significant 
Standardbred trotters

$\mathrm{n}=372$

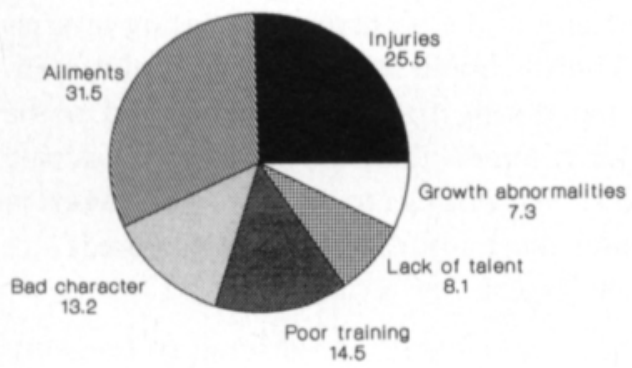

Fig. 3a
Finnhorse trotters

$n=243$

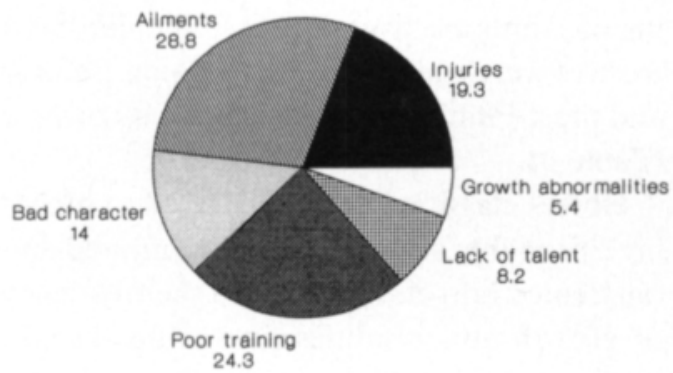

Fig. 3b

Fig. 3. Influence of class of instructor (a) and class of trainer (b) on best time in Standardbred trotters.

also include poor durability and unsoundness occurring during the training period. The higher frequency of injuries in Standardbred trotters compared to that in Finnhorses may be due to the higher training intensity and the more stressful training environment of Standardbred trotters.

Poor training as a reason for inferior per-

Table 5. Effect of class of age at onset of training on performance traits.

1 = early traineda, 2 = late trained (see text).

\begin{tabular}{|c|c|c|c|c|c|}
\hline \multirow[t]{2}{*}{$\begin{array}{l}\text { LS- } \\
\text { mean }\end{array}$} & \multicolumn{2}{|c|}{$\begin{array}{l}\text { Class of age at } \\
\text { onset of training }\end{array}$} & \multirow[t]{2}{*}{$\begin{array}{l}\text { F- } \\
\text { test }\end{array}$} & \multirow[t]{2}{*}{$\begin{array}{l}\text { LS- } \\
\text { mean }\end{array}$} & $\begin{array}{c}\text { Class of age at } \\
\text { onset of training }\end{array}$ \\
\hline & 1 & 2 & & & 1 \\
\hline
\end{tabular}

Standardbred trotter

Best time (sec.)

$\begin{array}{ll}3 & 84.96 \\ 4 & 83.25 \\ 5 & 82.47\end{array}$

Number of starts

$\begin{array}{lr}3 & 7.73 \\ 4 & 14.16 \\ 5 & 15.85\end{array}$

14.16
15.85

(Earnings)

$\begin{array}{rrrrr}3 & 4.13 & 0 & -0.40 & \text { ns } \\ 4 & 4.48 & 0 & -0.30 & \text { ns } \\ 5 & 4.30 & 0 & 0.00 & \text { ns }\end{array}$

Logit (first placings)$$
5
$$

Logit (1st to 3 rd placings)

$$
\begin{aligned}
& \text { Logit (1st to 3rd placings) } \\
& 3 \\
& 4
\end{aligned}
$$

$$
\begin{array}{ll}
\text { Logit (disqualified races) } \\
3 & -1.46 \\
4 & -1.73 \\
5 & -1.81 \\
\hline
\end{array}
$$

-1.46
-1.73
-1.81

$$
\begin{array}{r}
+1.90 \\
+1.04 \\
+0.22
\end{array}
$$$$
-3.00
$$$$
-1.40
$$$$
+0.12
$$$$
-0.08
$$$$
-0.12
$$$$
-0.10
$$

$-0.24$

$-0.06$

0.00

$+0.12$

$+0.18$

0.00
Finnhorse trotter

Best time (sec.)

$\begin{array}{rrrrr}5 & 104.44 & 0 & +3.32 & * * \\ 5 & 101.00 & 0 & +2.88 & * * \\ 6 & 98.84 & 0 & +2.00 & *\end{array}$

Number of starts

$\begin{array}{rrrrr}4 & 8.36 & 0 & -2.80 & * * \\ 5 & 14.10 & 0 & -2.40 & \text { ns } \\ 6 & 15.00 & 0 & -2.27 & \text { ns }\end{array}$

(Earnings) ${ }^{1 / 4}$

$\begin{array}{lllll}4 & 3.65 & 0 & -0.65 & \text { ns } \\ 5 & 4.15 & 0 & -0.40 & * * \\ 6 & 4.28 & 0 & -0.25 & \text { ns }\end{array}$

Logit (first placings)

$\begin{array}{lllll}4 & -1.88 & 0 & -0.22 & \text { ns } \\ 5 & -2.15 & 0 & -0.13 & \text { ns } \\ 6 & -2.14 & 0 & -0.18 & \text { ns }\end{array}$

Logit (1st to 3rd placings)

$\begin{array}{lllll}4 & -1.05 & 0 & -0.36 & * \\ 5 & -1.02 & 0 & -0.31 & * \\ 6 & -1.11 & 0 & -0.16 & \text { ns }\end{array}$

Logit (disqualified races)

$\begin{array}{lllll}4 & -1.54 & 0 & +0.20 & \text { ns } \\ 5 & -1.75 & 0 & +0.26 & \text { ns } \\ 6 & -1.71 & 0 & +0.05 & \text { ns }\end{array}$


formance was more important in Finnhorses than in Standardbred trotters. This was probably associated with the small proportion of professional trainers responsible for the training of Finnhorse trotters. Most Standardbred trotters were trained by professional trainers and most Finnhorses were trained by owners (Table 3).

Horses classified as "transferred to breeding" probably also included sick, injured and untalented horses. In regard to the frequency of growth abnormalities, it was not known how the incidence of these cases was diagnosed. However, growth abnormalities were more common in Standardbred trotters than in Finnhorses.

Even most trotters succeeded worse in their races than expected by their owners, the number of starts observed was larger than that presented for an average Finnish Standardbred trotter and Finnhorse trotter belonging to the same crops studied here (ANON. 1983, 1984, 1985, 1986, 1987).

The reasons for non-starting and poor performance agreed with those presented for nonand late starting in trotters in Nordic countries (Bendroth 1981, Klemetsdal et al. 1985, Andersson-Eklund 1988, SaAstamoiNEN 1991). Thafvelin and Magnusson (1985) reported that 4-year-old trotters which never raced had worse orthopedic health compared to raced trotters, and that trotters with poor orthopedic health had a smaller number of starts compared to trotters with good orthopedic health.

The main reasons for non-starting and poor racing results in Thoroughbreds have also been reported to be injuries and a variety kinds of ailments (DARENIUS and STRÖM 1979, JEFFCOTt et al. 1982).

Hoppe and Philipsson (1984) reported a lower racing capacity for trotters with osteochondrosis (OCD) compared to those trotters without OCD. Morris and SeEherman (1991) reported that 84 per cent of horses with poor performance suffered from more than one health problem.

According to FrEdRicson et al. (1975) the condition and design of racetracks have a large influence on the soundness of trotters' limbs. On the other hand, Hill et al. (1986) concluded that track condition was of no importance in the occurrence of racing injuries to Thoroughbred horses, and that injuries incurred during training were believed to be more common than those occurring during races. According to KROOK and MAYLIN (1989) most injuries in Thoroughbreds are pathological.

Effect of class of age at onset of breaking and training. It can be supposed that horses beginning breaking and training earlier than their racemates were more talented and mature. They might also be sounder and more resistant to injuries compared to the horses beginning late (BENDROTH 1981, DARENIUS et al. 1983, SaAstamoinen 1991), and could thus start earlier and race more frequently.

The influences of age at breaking and training may be overestimated because some horses discontinued their careers after one or two racing seasons. On the other hand, some horses whose breaking and training was started early might have been delayed in starting to race due to different reasons.

The practice of beginning breaking and training at an early age has been stated to be advantageous to the performance of the horse (LindHOLM 1988). A Standardbred foal should be broken at 11/2 years of age (RONEUs 1987, LindHOLM 1988). Training a growing horse is benefical to the development of its bones, musculature, tendons, respiratory organs and circulatory system. In addition, a negative correlation has been observed between age and rate of learning (MADER and PRICE 1980) which, in turn, is positively correlated with trainability (FISKE and POTTER 1979).

Starting to race at an early age has been observed to favorably influence the racing results of young trotters (PHYSICKSHEARD 1986a; SaAstamoinen and Ojala 1988). Minkema (1975) reported that early mature horses did not win more money during their career than later mature horses. 
Effect of class of instructor and trainer. Due to the small influence of class of instructor and class of trainer, it can be assumed that there were no differences in the training methods among different intsructor and trainer groups. The differences between trainer groups in best time in three- and four-yearold Standardbred trotters may be due to differences in the talent and maturity of horses; most talented and well developed horses were driven to broken and trained by professional trainers. HINTZ and Van VLECK (1978) reported a significant effect of the driver on racing results in pacers. In Finland, many trotters trained by owners are driven in races by professional trainers.

Effect of sex, birth-month class and birth year. The superiority of males to females was in agreement with many previous studies (i.a. Ojala 1982, Bendroth et al. 1985; Ojala and Hellman 1987). The influence of birth month agreed with PHYSICKSHEARD (1986b) and SaAstamoinen and Ojala (1991).

The influence of birth year was slight probably because the number of consecutive birth years was only two.

\section{References}

ANON., 1983-1987. Suomen raviurheilun vuositilastot 1984-87 (Annual statistics on trotting in Finland). Suomen Hippos, Helsinki.

ANoN., 1987b. Ravikilpailusăănnöt (Rules for harness racing). Suomen Hippos, Helsinki.

Andersson-Eklund, L. 1988. Possible explanations for the association between serum esterase (Es) type and starting proportion in Swedish trotters - an inquiry study. Rapport 80, Swedish Univ. of Agric. Sci., Dep. of Anim. Breed. and Gen., Uppsala.

Bendroth, M. 1981. A survey of reasons for some trotters being non-starters as 2-, 3-, and 4-years olds. $\mathrm{Pa}$ per, 32nd Ann. Meet. of Eur. Assoc. for Anim. Prod.

-, Arnason, T. \& Philipsson, J. 1985. Genetic and environmental factors affecting trotting performance of Swedish trotters. Paper, 36th Ann. Meet. of Eur. Assoc. for Anim. Prod.

Darenius, A. \& Strom, H. 1979. A survey of problems in Swedish trotter and Thoroughbred racing. Paper, 30th Ann. Meet. of Eur. Assoc. for Anim. Prod.

\section{Conclusions}

Young age at the onset of breaking and training seemed to be favorably associated with the racing performance of young trotters. Horses whose breaking and training was started early might have been more mature, sounder and more resistant to injuries than other horses. The influence of class of persons responsible for breaking and training was minor, indicating slight differences in training methods. The main reasons for non-starting and poor racing performance were injuries and ailments, bad character, lack of talent and poor training.

The present study should be regarded as a pilot investigation, and its results will only reveal trends and provide some insight into the influencing factors due to the small and subjective data set. It is also possible that the data are selected because owners of horses with certain problems might have been more interested in responding to the questionnaire.

Acknowledgements. The author wishes to thank Prof. Matti Ojala for critically reviewing the manuscript.

-, Bendroth, M., Arnason, T. \& Philipsson, J. 1983. Tävlingsstatistik som underlag för genetiska studier av travares "hăllbarhet". Svensk Veterinärtidning 35, suppl. 3: 49-51.

Fiske, J.C. \& PotTer, G.D. 1979. Discrimination reversal learning in yearling horses. J. Anim. Sci. 49: $583-588$.

Fredricsson, I., Dalin, G., Drevemo, S., Huerten, G., Nilsson, G. \& Alm, L.O. 1975. Ergonomic aspects of poor racetrack design. Equine Vet. J. 7: 63-65.

Hill, T., Carmichael, D., Maylin, G. \& Krook, L. 1986. Track condition and racing injuries in Thoroughbred horses. Cornell Vet. 76: 361-379.

HINTZ, R.L. \& Van VLECK, L.D. 1978. Factors influencing racing performance of the Standardbred pacer. J. Anim. Sci. 46: 60-68.

Hoppe, F. \& Philıpsson, J. 1984. Tävlingsresultat hos travhăstar med osteochondros i hasleden. Svensk Veterinärtidning 36: 285-288.

Jeffcott, L.B., Rossdale, P.D., Freestone, J., Frank, 
C.J. \& Towers-Clark, P.F. 1982. An assessment of wastage in Thoroughbred racing from conception to 4 years of age. Equine Vet. J. 14: 185-198.

KATONA, Ö. 1985. Research in breeding of the trotter. Paper, 36th Ann. Meet. of Eur. Assoc. for Anim. Prod.

Klemetsdal, G., Svendsen, M. \& Vangen, O. 1985. Preliminary results from genetic studies of racing performance in Norwegian trotters. Paper, 36th Ann. Meet. of Eur. Assoc. for Anim. Prod.

Krook, L. \& MaYlin, G.A. 1989. Race horses at risk. 205 p. Ithaca, New York.

LINDHOLM, A. 1988. Unghästtrăning och starter med 2-åringar. Trav- och galoppronden, Vinternummer 1988, pp. 228-231.

,- 1990 . Different methods of training of the Standardbred trotter. Proc. of the Int. Conf. on Equine Sports Med., 36-39.

Mader, D.R. \& Price, E.O. 1980. Discrimination learning in horses: Effect of breed, age and social dominance. J. Anim. Sci. 50: 962-965.

Morris, E.A. \& Seeherman, H.J. 1991. Clinical evaluation of poor performance in the racehorse: the results of 275 evaluations. Equine Vet. J. 23: 169-174.

MinkemA, D. 1975. Studies on the genetics of trotting performance in Dutch trotters. I. The heritability of trotting performance. Ann. Genet. Sel. Anim. 7: 99-121.

OJALA, M. 1982. Some parameters estimated from a restrected set of race records in trotter. Acta Agric. Scand. 32: 215-224.

\section{SELOSTUS}

\section{Eräiden opetuksen ja valmennuksen aikaisten tekijöiden vaikutus nuoren ravihevosen kilpailutuloksiin}

\section{Markku Saastamoinen}

\section{MTTK hevostalouden tutkimusasema, 32100 Ypajja}

Ravihevosten omistajille tehdyllä kyselytutkimuksella selvitettiin syitä hevosten kilpailemattomuuteen ja heikkoon kilpailumenestykseen, sekă arvioitiin eräiden opetuksen ja valmennuksen aikaisten tekijöiden vaikutusta kilpailutuloksiin. Hyväksyttăvien vastausten mäără oli 796 lămminverisillä ravihevosilla ja 857 suomenhevosilla. Lămminverisistă oli kilpaillut viimeistăän viisivuotiaana $72 \%$ ja suomenhevosista viimeistaaăn kuusivuotiaana $42 \%$. Tärkeimmăt syyt kilpailemattomuuteen ja huonoon kilpailumenestykseen olivat loukkaantumiset ja sairastelu, huono luonne, lahjattomuus ja huono valmennus. Aikaisin opetukseen ja valmennukseen tulleet hevoset menes-
- \& Hellman, T. 1987. Effects of year, sex, age and breed on annually summarized race records for trotters in Finland. Acta Agric. Scand. 37: 463-468.

Physick-SheARd, P.W. 1986a. Career profile of the Canadian Standardbred I. Influence of age, gait and sex upon chances of racing. Can. J. Vet. Res. 50: 449-456.

—, 1986b. Career profile of the Canadian Standardbred II. Influence of age, gait and sex upon number of races, money won and race times. Can. J. Vet. Res. 50: $457-470$.

RONEUS, M. 1987. Träningseffekter på muskulaturen hos trav- och galopphästar. Svensk Veterinärtidning 39, suppl. 14: 105-107.

SaAstamoinen, M. 1991. Factors affecting age at onset of breaking, training qualifying and first start in Finnish trotters. Acta Agric. Scand. 41: 137-145.

- \& OJALA, M. 1988. Influence of birth month on race track records in young trotters. Paper, 6th World Conf. on Anim. Prod.

- \& OJAlA, M. 1991. Influence of birth-month on age at first start and racing performance in young trotters. Acta Agric. Scand. 41: 437-445.

Thafvelin, B. \& Magnusson, L.E. 1985. Relationships between the conformation and performance of 4-year old Standardbred trotters. In: Studies on the conformation and related traits of Standardbred trotters in Sweden. Doctoral thesis, Swedish Univ. of Agric. Sci., Fac. of Vet. Sci.

Ms received February 28, 1991 tyivăt myőhăän aloittaneita ikătovereitaan paremmin. Esimerkiksi lămminveriset, joilla opetus aloitettiin 1- tai $1 \frac{1}{2}$-vuotiaana olivat 2.1 sekuntia nopeampia $(\mathrm{p}<0.01)$ kolmevuotiaana kuin ne, joilla opetus oli aloitettu 2- tai 3-vuotiaana. Niillă oli myös kilpailtu useammin $(\mathrm{p}<0.05)$. Opetuksen ja valmennuksen suorittaneiden henkilöluokkien (kasvattaja, omistaja, ammattivalmentaja) väliset erot hevosten kilpailumenestyksessä olivat pienet. Ammattivalmentajien opettamat ja valmentamat hevoset näyttivät kuitenkin menestyneen kasvattajien ja omistajien opettamia ja valmentamia hevosia paremmin. 